\title{
POLA PEMBINAAN KEPRIBADIAN DAN KEAGAMAAN REMAJA MASJID AL-FATAH DI KELURAHAN GIRIAN INDAH KECAMATAN GIRIAN KOTA BITUNG
}

\author{
Prasetio Rumondor \\ Universitas Islam Negeri Sunan Kalijaga Yogyakarta, thiorumondor@gmail.com \\ Puspasari M. Y. Gobel \\ Institut Agama Islam Negeri (IAIN) Manado, puspasarigobe109@gmail.com
}

\begin{abstract}
The rapid development of technology and the influence of the environment is very instrumental in shaping adolescents. There are many cases involving teenagers, this is a problem in the process of Islamic education in adolescents. Therefore, BTM Al-Fatah decided to establish youth mosque in order to avoid them from this influence. This research aimed to know how the coaching pattern of personality and religious adolescent Al-Fatah mosque. The data analysis used was qualitative descriptive analysis. The results showed that the emphasis is on the pattern of mosque youth coaching through the alignment of mosque youth activities with BTM activities, hence they might synergize and strengthen each other. There are studies about Islam to form an Islamic character for mosque youth and to support mosque youth activities such as quality training in Basic Leadership Training and skills training in computer training funded by BTM, attitude personality development, and refresher are almost similar to skills training. Efforts to overcome the problem are to continue to foster and support mosque youth activities in financial terms, creating a conducive environment when there are disputes between the management of BTM and the Imam of the Mosque and keep activating vacuum activities so that mosque youth can work and innovate in positive activities.
\end{abstract}

Keywords: coaching patterns; youth; mosque youth.

\begin{abstract}
Abstrak
Perkembangan teknologi yang begitu pesat dan pengaruh lingkungan sangat berperan dalam membentuk pribadi remaja. Ada banyak kasus yang melibatkan remaja, hal ini menjadi permasalahan dalam proses pendidikan Islam pada remaja. Oleh karena itu, BTM Al-Fatah memutuskan untuk membentuk remaja masjid bertujuan untuk menghindarkan mereka dari pengaruh tersebut. Penelitian ini bertujuan untuk mengetahui bagaimana pola pembinaan kepribadian dan keagamaan remaja masjid Al-Fatah. Analisis data dengan menggunakan analisis deskriptif kualitatif. Hasil penelitian menunjukkan bahwa titik penekannya adalah pola pembinaan remaja masjid melalui penyelarasan kegiatan remaja masjid dengan aktivitas BTM sehingga bersinergi dan saling menguatkan, adanya kajian seputar agama Islam supaya membentuk karakter islami bagi remaja masjid, mendukung kegiatan remaja masjid seperti pembekalan kualitas dalam Latihan Dasar Kepemimpinan dan pembinaan kecakapan dalam pelatihan komputer yang dibiayai oleh BTM, pengembangan kepribadian sikap, dan penyegaran yang hampir mirip dengan pembinaan kecakapan. Upaya mengatasi masalah yaitu tetap membina dan mendukung kegiatan remaja masjid dari segi keuangan, menciptakan lingkungan yang kondusif dikala ada perselisihan antar para pengurus BTM dan
\end{abstract}


Keimaman Masjid dan tetap mengaktifkan kegiatan yang vakum agar remaja masjid bisa berkarya dan berinovasi dalam kegiatan yang positif.

Kata Kunci: pola pembinaan; remaja; remaja masjid.

\section{A. Pendahuluan}

Masjid adalah tempat beribadahnya umat Islam, bangunan yang berhubungan dengan manusia dan lingkungan sosial masyarakat. Masjid bukan hanya tempat sholat lima waktu, tempat yasinan, maupun tempat pengajian ibu-ibu atau bentuk gedung dan motif interiornya yang indah. Akan tetapi, masjid harusnya dijadikan tempat berkumpulnya umat Islam untuk mengakaji dan mendalami agama Islam sehingga timbul kecintaan terhadap tempat ibadah dan Islam yang dianut. Masjid merupakan pusat kegiatan kaum Muslim. Dari sanalah seharusnya umat Muslim merancang masa depannya, baik dari agama, ekonomi, politik, soisal, dan seluruh sendiri kehidupannya, sebagaimana para pendahulunya memfungksikan masjid secara maksimal. ${ }^{1}$

Sebenarnya masjid dan remaja memiliki hubungan yang sangat erat. Akan tetapi, remaja zaman now tidak terlalu terlibat dalam mewaujudkan fungsi dan tujuan didirikannya masjid. Sehubungan dengan hal itu, maka marilah kita membuka dan membaca fungsi dan tujuan dari masjid dalam keputusan Agama RI nomor 505 tahun 2003 tentang susunan organisasi dan tata kerja Badan Kesejahteraan masjid, yaitu: Meningkatkan idarah, imarah dan riayah masjid dan tempat Ibadah umat Islam lainnya, sesuai dengan fungsinya sebagai tempat ibadah, pusat pendidikan agama Islam non formal dan pemberdayaan ekonomi umat serta media kesehatan umat. ${ }^{2}$

Dalam paragdima diatas, remaja tidak terlalu memahaminya bahkan jarang remaja masjid tahu akan hal itu. Itu dikarenakan remaja zaman now lebih tertarik pada perkembangan ilmu pengetahuan dan teknologi serta kesenangan duniawi.

Perkembangan ilmu pengetahuan dan teknologi yang sangat pesat membuat remaja sebagai sasaran pada kemajuan tersebut. Hingga para remaja pada umumnya lebih tergiur akan kecanggihan ilmu pengetahuan dan teknologi (IPTEK) tanpa bisa menyeimbanginya dengan iman dan takwa (IMTAK). Disi lain, IPTEK yang semakin canggih dan mutakhir, media cetak dan elektronik mempunyai andil yang cukup besar dalam mewarnai gaya hidup remaja, pola pikir dan perilaku mereka bisa jadi semakin jauh dari ajaran agama Islam. $^{3}$ Misalnya teknologi informasi dan komunikasi yang ada banyak digunakan untuk melakukan perilaku menyimpang seperti penipuan, mencontek ketika ujian nasional, mengunduh film dewasa yang dapat menyebabkan penurunan moralitas. ${ }^{4}$ Selain itu, kenakalan remaja semakin meningkat yang diantaranya marak terjadi kasus begal motor di Indonesia belakangan ini,

\footnotetext{
${ }^{1}$ Asadullah Al-Faruq, Panduan Lengkap Mengelola Dan Memakmurkan Masjid (Solo: Pustaka Arafah, 2010), 265.

${ }^{2}$ Ahmad Buwaethy, Kriteria Tipologi Masjid (Jakarta: Dirjen Bimbaga Islam, 2004), 80.

${ }^{3}$ Zulmoran, Muhammad Noupal \& Sri Aliyah, "Peran Sosial Keagamaan Remaja Masjid Di Kelurahan Pipa Reja Kecamatan Kemuning Palembang,” Jurnal Studi Agama 1, no. 1 (2017): 42.

4 Ana Puji Astuti \& Anike Nurmalita Rps, "Teknologi Komunikasi Dan Perilaku Remaja," Jurnal Analisa Sosiologi 3, no. 1 (2014): 92.
}

Prasetio Rumondor, Puspasari M. Y. Gobel 
diketahui bahwa banyak pelaku kekerasan tersebut justru dilakukan oleh para remaja. ${ }^{5}$ Secara tidak langsung remaja saat ini melupakan norma-norma yang sudah ada dan sudah diterapakan oleh orang-orang tua kita, baik itu norma kesusilaan, norma sosial, norma agama ataupun yang lainnya.

Dengan adanya realita remaja saat ini yang semakin parah, banyak kegiatan masyarakat yang sekiranya dapat membantu para remaja untuk berada di jalan yang benar. Contohnya seperti organisasi-organisasi keagamaan, mulai dari IPNU (Ikatan Pelajar Nahdatul Ulama), IPPNU (Ikatan Pelajar Putri Nahdatul Ulama), IPM (Ikatan Pelajar Muhammadiyah), IMM (Ikatan Mahasiswa Muhammadiyah), Himpunan mahasiswa Islam (HmI) dan masih banyak lagi organisasi yang ada di negeri ini. Dan ada juga organisasi kecil yang hampir setiap masjid memiliki organisasi ini yang lebih dikenal dengan istilah Remaja Masjid.

Bertitik dari penjelasan diatas maka masa remaja adalah saat-saat pembentukan pribadi, dimana lingkungan sangat berperan. Kalau diperhatikan ada empat faktor lingkungan yang mempengaruhi remaja, yaitu lingkungan keluarga, sekolah, teman pergaulan dan dunia luar. Ramaja memiliki energi yang besar disertai dengan emosi yang berkobar-kobar. ${ }^{6}$ Maka dari itu, lingkungan yang dibutuhkan oleh remaja adalah lingkungan yang Islami, yang mendukung perkembangan imajinasi mereka secara positif dan menuntun mereka pada kepribadian yang benar. Lingkungan yang Islami akan memberi kemudahan dalam pembinaan remaja. Karena remaja membutuhkan lingkungan yang Islami, maka remaja masjid merupakan salah satu cara untuk bisa membentengi diri dari hal-hal yang bersifat negatif.

Kota Bitung adalah salah satu kota di provinsi Sulawesi Utara. Kota ini memiliki Remaja Masjid Al-Fatah yang berada di Kelurahan Girian Indah Kecamatan Girian yang dibentuk karena beberapa hal, salah satunya untuk menghindari agar supaya remaja-remaja yang ada tidak tergiur dengan kemajuan Ilmu Pengetahuan dan Teknologi yang dapat menyesatkan mereka. Karena hal itu, mereka mengenyampingkan norma-norma yang ada lebih khusus norma agama agar bisa menjadi netralisir perilaku remaja.

Seiring dengan waktu, Badan Ta'mirul Masjid memutuskan untuk membentuk Remaja Masjid, yang di dalamnya terdapat beberapa kegiatan yang membuat remaja disibukkan dengan kegiatan-kegiatan positif agar supaya tidak terkena dampak negatif dari Ilmu Pengetahuan dan Teknologi serta agar tidak melanggar norma-norma yang ada dimasyarakat.

Namun dalam proses pembinaan remaja tidaklah semudah yang kita bayangkan. Remaja yang melanggar norma-norma dalam masyarakat merupakan sebuah penyakit sosial yang dapat menganggu kelancaran dalam pembinaan kepada remaja lainnya. Menurut Kartono bahwa penyakit sosial yang diakibatkan dari dilanggarnya norma-norma umum merupakan sebuah penyakit sosial, karena gejalanya berkembang menjadi akses sosial yang

5 Nahed Nuwairah, "Peran Keluarga Dan Organisasi Remaja Masjid Dalam Dakwah Terhadap Remaja," Al-Hiwar 3, no. 6 (2015): 1.

${ }^{6}$ Ibid. 9. 
mengganggu keutuhan dan kelancaran berfungsinya organisasi sosial, disamping itu pula bagian satu struktur sosial tersebut berkembang tidak seimbang dengan bagian-bagian lain (misalnya person, anggota suku, klien, dan lain-lain). ${ }^{7}$ Ketidaksamaan persepsi antara BTM dan keimaman masjid, dukungan dari orangtuapun masih kurang dan adanya rangkap jabatan di lingkungan masjid yang dapat membuat pekerjaan terbagi. ${ }^{8}$ Selain itu, dalam penelitian Herman bahwa pola pembinaan remaja masjid semakin terhambat dalam upaya pemberdayaan masjid sebagai wadah pembangunan agama masyarakat, disamping kurangnya perhatian dari pihak pemerintah begitu juga dari tokoh agama, masyarakat serta dengan orangtua remaja masjid, untuk melibatkan diri secara langsung dalam pembinaan keagamaan dan masjid. Sehingga prosesnya bisa mengganggu, menghambat, atau bahkan merugikan bagian-bagian lain, karena tidak dapat di integrasikan menjadi satu totalitas yang utuh. ${ }^{9}$

Riset yang difokuskan mengenai pola pembinaan telah banyak dilakukan, diantaranya dilakukan oleh Herman dalam pola pembinaan remaja mesjid Nurul Jihad kelurahan Tipulu kecamatan Kendari Barat. ${ }^{10}$ Penelitian ini menemukan bahwa titik penekanan dalam pembinaan remaja masjid dilakukan dilingkungan keluarga, mengadakan seminar atau pelatihan, membentuk organisasi remaja dibawah instansi tertentu, mengadakan kajian seputar agama Islam dan mengadakan bakti sosial. Penelitian Taufiq dalam pembinaan kepada mahasiswa menunjukkan bahwa proses pembinaan secara parsial dengan melibatkan unit-unit lembaga seperti bagian pengajaran AIK, badan pemakmuran masjid dan program pengembangan kepribadian dan kepemimpinan yang kemudian masing-masing unit melakukan kegiatan pelatihan, pengakajian, ceramah dan lain sebagainya. ${ }^{11}$ Penelitian Marjuni dan Sodiq menemukkan bahwa dalam pola pembinaan bukan hanya pada siswa tetapi kepada tutor pula dengan cara mengikutkan tutor pada pelatihan, seminar, dan membuat tutor bergabung dengan organisasi prosesi. ${ }^{12}$ Maka dari itu, keterlibatan pengurus masjid dan institusi tak dapat dipungkiri dapat membantu proses pembinaan kepada remaja, mahasiswa maupun tutor sehingga pembinaan berjalan lancar dan berhasil.

Pembinaan kepribadian dan keagamaan merupakan unsur penting di dalam memahamkan remaja mengenai agama dan membentuk kepribadiannya, dengan begitu remaja bisa membentengi diri dan dapat terhindar dari hal yang menyimpang. Sebagaiman penelitian yang dilakukan Nuwairah tentang Peran Keluarga dan Organisasi Remaja Masjid dalam Dakwah Terhadap Remaja. ${ }^{13}$ Penelitian ini menemukan bahwa dalam proses

\footnotetext{
${ }^{7}$ Kartini Kartono, Patologi Sosial 2 Kenakalan Remaja (Jakarta: PT Raja Grafindo Persada, 2002), 4.

${ }^{8}$ Norika Aunaka, Pembina Remaja Masjid, Wawancara, Tanggal 27 Februari 2017.

${ }^{9}$ Kartono, Patologi Sosial 2 Kenakalan Remaja, 5.

${ }^{10}$ Herman, "Pola Pembinaan Remaja Mesjid Nurul Jihad Kelurahan Tipulu Kecamatan Kendari Barat," Al-Izzah: Jurnal Hasil-Hasil Penelitian 8, no. 2 (November 1, 2013): 92-103.

${ }^{11}$ HN Taufiq, "Pola Pembinaan Keagamaan Dan Akhlak Mahasiswa (Studi Kasus Di Universitas Muhammadiyah Malang)," Progressiva 4, no. 1 (2010): 45-60.

12 Marjuni \& Sodiq AK, "Pola Pembinaan Anak Usia Prasekolah Melalui Prinsip-Prinsip Bermain Sambil Belajar (Studi Di Tempat Penitipan Anak Indrya Paramartha Yogyakarta)," Jurnal Penelitian Dan Evaluasi Pendidikan 3, no. 4 (2001): 62-79.

13 Nahed Nuwairah, "Peran Keluarga dan Organisasi Remaja Masjid dalam Dakwah Terhadap Remaja," Al-Hiwar : Jurnal Ilmu dan Teknik Dakwah 3, no. 6 (July 2015): 1-12.
} 
pembangunan kepribadian remaja bukan hanya keluarga dan orang tua. Namun, tanggung jawab bersama orang tua, guru-guru di sekolah, para dai dan tokoh agama di lingkungan masyarakat. Begitu pula dengan pembinaan keagamaan kepada remaja harus dilakukan secara menyeluruh yang melibatkan partisipasi seluruh pihak.

Penelitian ini akan memperkaya penelitian-penelitian yang sudah dilakukan sebelumnya pada pola pembinaan di salah satu kota di Sulawesi Utara. Bagaimanapun, penelitian ini berbeda dengan penelitian-penelitian sebelumnya, dimana pola pembinaan kepada remaja masjid sungguh-sungguh atas inisiatif dari pengurus masjid yaitu BTM dan Keimaman Masjid dimana mereka resah dan khawatir bila remaja yang ada di kelurahan Girian Indah akan terjerumus pada hal-hal yang menyimpang sehingga melanggar normanorma yang ada pada masyarakat. Maka dari itu, pengurus masjid membuat organisasi kemasjidan yaitu Remaja Masjid yang pada strukturnya langsung dibawah BTM dan Keimaman.

Penelitian ini merupakan penelitian kualitatif deskriptif, yang memfokuskan pada permasalahan pola pembinaan keagamaan dan kepribadian remaja masjid Al-Fatah di Kelurahan Girian Indah Kecamatam Girian Kota Bitung. Data yang digunakan dalam penelitian ini merupakan data primer yang diperoleh dari imam masjid Al-Fatah, pembina remaja masjid Al-Fatah, ketua remaja masjid Al-Fatah dan anggota remaja masjid Al-Fatah. Pengumpulan data menggunakan teknik observasi, dan wawancara mendalam serta dokumentasi. Analisis data dilakukan melalui proses analisis deskriptif kualitatif. Selanjutnya diuji apakah data yang diperoleh dalam penelitian itu sah dan benar maka dilakukan uji keabsahan dengan triangulasi yakni triagulasi sumber, tehnik dan waktu. Oleh karena itu tulisan ini bertujuan untuk mengetahui bagaimana pola pembinaan keagamaan dan kepribadian pada remaja masjid Al-Fatah Kelurahan Girian Indah Kecamatan Girian Kota Bitung.

\section{B. Temuan Penelitian}

\section{B.1 Pola Pembinaan}

Kehidupan beragama salah satu diantara sekian banyak sektor harus mendapatkan perhatian besar bagi bangsa dibandingkan dengan sektor kehidupan yang lain. Sebab pencapaian pembangunan bangsa yang bermoral dan beradab sangat ditentukan dari aspek kehidupan agama, terutama dalam hal pembinaan bagi generasi muda. ${ }^{14}$

Mangun Hardjana menyatakan bahwa pembinaan adalah terjemahan dari kata training, yang mengartikan pembinaan sebagai latihan, pendidikan, pembinaan. Jadi, pembinaan disini menekankan pada pengembangan sikap, kemampuan dan kecakapan. Mangun Hardjana dalam bukunya bahwa pembinaan pembantu orang untuk mengenal hambatan-hambatan baik yang ada di dalam situasi hidup dengan melihat segi-segi positif dan negatifnya, serta menemukan cara-cara pemecahannya. Pembinaan dapat menimbulkan

${ }^{14}$ Zakiah Daradjat, Pendidikan Agama Dalam Pembinaan Mental (Jakarta: PT Bulan Bintang, 1982), 12. 
serta menguatkan motivasi orang untuk mendorongnya mengambil dan melaksanakan salah cara yang terbaik guna mencapai tujuan dan sasaran hidupnya. ${ }^{15}$ Pembinaan juga dapat berarti suatu kegiatan yang mempertahankan dan menyempurnakan apa yang telah ada sesuai dengan yang diharapkan. ${ }^{16}$

Berdasarkan penjelasan di atas, dapat dipahami bahwa pola pembinaan adalah suatu usaha yang mempertahankan dan menyempurnakan sesuatu yang ada untuk menjadikannya lebih baik agar dapat melakukan tindakan yang sesuai dengan prosedur baik itu berlandaskan nilai-nilai dan norma-norma yang telah ditetapkan baik dari negara maupun dari agama.

Pembinaan menurut macamnya dikenal ada pembinaan orientasi, pembinaan kecakapan, pembinaan kepribadian, pembinaan penyegaran, pembinaan lapangan.

a. Pembinaan Orientasi

Pembinaan orientasi (orientasi program), diadakan untuk sekelompok orang yang baru masuk dalam suatu bidang hidup dan keja. Bagi orang yang sama sekali belum berpengalaman dalam bidangnya, pembinaan orientasi ini membantunya untuk mendapatkan hal-hal pokok.

b. Pembinaan Kecakapan

Pembinaan kecakapan (skill training) diadakan untuk membantu para peserta guna mengembangkan kecakapan yang sudah dimiliki atau mendapatkan kecakapan baru yang diperlukan untuk melaksanakan tugasnya.

c. Pembinaan Pengembangan Kepribadian

Pembinaan pengembangan kepribadian (personality development training), tekanan pembinaan ini ada pada pengembangan kepribadian sikap. Pembinaan ini sangat berguna bagi anak asuh, agar dapat mengembangkan diri menurut cita-cita.

d. Pembinaan Penyegaran

Pembinaan penyegaran (refresing training), hampir sama dengan pembinaan kerja. Hanya bedanya, dalam pembinaan penyegaran biasanya tidak ada penyajian hal yang sama sekali baru, tetapi sekedar penembahan cakrawali pada pengetahuan dan kecakapan yang sudah ada.

e. Pembinaan Lapangan

Pembinaan lapangan (field training), bertujuan untuk menempatkan para peserta dalam situasi nyata, agar mendapat pengetahuan dan memperoleh pengalaman langsung dalam bidang yang diolah dalam pembinaan. ${ }^{17}$

\section{B.2 Remaja Masjid}

Remaja merupakan anak manusia yang memiliki dunianya sendiri mulai dari mencari hal menyenangkan, mencari identitas diri dan memiliki semangat dan emosi. Sementara, disi

\footnotetext{
${ }^{15}$ A. M. Mangunharjana, Pembinaan Arti Dan Metodenya (Yogyakarta: Kanisius, 1986), 15.

${ }^{16}$ Hendyat Soetopo \& Wanty Soemanto, Pembinaan Dan Pengembangan Kurikulum (Jakarta: Bumi Aksara, 1982), 23.

${ }^{17}$ Mangunharjana, Pembinaan Arti Dan Metodenya, 11-12.
} 
lain, masa remaja adalah masa transisi antara masa anak-anak dan masa remaja yang mengalami perubahan kejiwaan sangat kompleks karena sudah mengenal dunia luar. ${ }^{18}$

Remaja merupakan anak manusia yang memiliki dunianya sendiri mulai dari mencari hal menyenangkan, mencari identitas diri dan memiliki semangat dan emosi. Sementara, disi lain, masa remaja adalah masa transisi antara masa anak-anak dan masa remaja yang mengalami perubahan kejiwaan sangat kompleks karena sudah mengenal dunia luar.

Pada masa remaja tubuhnya akan mengalami perkembangan sedemikian pesat mulai dari perubahan fisik dan psikis, badannya akan menunjukkan tanda-tanda kedewasaan, perubahan perilaku yang kemudian ingin di akui keberadaannya dan berkembang wawasannya. Masa remaja diperkirakan pada umur 13 hingga 25 tahun.

Badan kesehatan Dunia (WHO) memberikan batasan mengenai siapa remaja secara konseptual. Dikemukakannya oleh WHO ada tiga kriteria yang digunakan: biologis, psikologis, dan sosial ekonomi, yakni: (1) individu yang berkembang saat pertama kali ia menunjukkan tanda-tanda seksusal sekundernya sampai saat ini mencapai kematangan seksual (2) individu yang mengalami perkembangan psikologis dan pola identifikasi dari anak-anak menjadi dewasa, dan (3) terjadi peralihan dari ketergantungan sosial ekonomi yang pernuh kepada keadaan yang mandiri. ${ }^{19}$

Emosionalitas puncaknya terjadi pada masa remaja yang ditunjukkan dari sifat sensitif dan reaksi pada sebuah situasi atau peristiwa yang sifatnya tidak baik atau bisa terjadi karena remajanya temparanen. Hal itu, terjadi karena perkembangan fisik misalnya organ seksual dan hal-hal yang mendorongnya bertindak. Maka dari itu, perlu adanya wadah dalam membatasi seksualnya yang kemudian menggantinya menjadi tindakan yang positif. Disinilah peran dan tugas dari Badan Takmir Masjid membentuk organisasi masjid yang dijalakan oleh para remaja. Disamping itu, remaja juga memiliki kekreatifitas yang tinggi kemudian hal itu menjadi sebuah nilai penting dalam menjalankan organisasinya.

Adapun ciri yang menonjol dari kehidupan generasi muda/remaja yaitu: kemurnian idealismenya, keberanian dan keterbukaanya dalam menyerap nilai-nilai dan gagasangagasan baru, semangat pengabdiannya, spontanitas dan dinamikanya, inovasi dan kreativitasnya, keinginan-keinginan untuk segera mewujudkan gagasan-gagasan baru, keteguhan janjinya dan keinginan untuk menampilkan sikap dan kepribadian yang mandiri dan masih langkanya pengalaman-pengalaman yang dapat merelevansikan pendapat, sikap dan tindakannya dengan kenyataan-kenyataan yang ada. ${ }^{20}$

Remaja masjid merupakan suatu wadah bagi remaja Islam yang cukup efektif dan efisien untuk melaksanakan aktivitas pendidikan Islam. Remaja-remaja berkepribadian muslim ini dapat melanjutkan harapan bangsa menuju cita-cita yang luhur dan berbudi pekerti yang baik sesuai dengan Pancasila dan Undang- Undang Dasar tahun 1945, adalah

18 Zulmoran, Muhammad Noupal \& Sri Aliyah, "Peran Sosial Keagamaan Remaja Masjid Di Kelurahan Pipa Reja Kecamatan Kemuning Palembang," 42.

${ }^{19}$ S. Wirawan, Psikologi Remaja (Jakarta: Raja Grafindo Persada, 2002), 23.

20 Ali Abdul Halim Mahmud, Karakteristik Umat Terbaik Telaah Manhaj, Akidah Dan Harakah (Jakarta: Gema Insani Press, 1996), 186. 
untuk mensejahterakan kesejahteraan umum, mencerdaskan kehidupan bangsa dan ikut melaksanakan ketertiban dunia yang berdasarkan kemerdekaan, perdamaian abadi dan keadilan sosial. ${ }^{21}$

Mewujudkan hal tersebut perlu adanya perhatian dan bimbingan yang terprogram dan terencana dalam hal ini tugasnya Badan Ta'mirul Masjid. Sehingga remaja masjid terlihat peranannya dalam mencapai cita-cita tersebut, tentunya peran utama nya adalah berhubungan dengan ajaran Islam.

Remaja masjid bertugas dalam mencurahkan semua pengetahuannya pada masjid mulai dari ajaran Islam yang ia dapat, pengalaman yang didapatkanya ditengah-tengah masyarakat sehingga ikut andil dalam menjamin kestabilan bangsa, dan saling tolong menolong dalam kebajikan.

Remaja Masjid merupakan suatu sarana untuk mempererat tali silaturahim baik dalam pergaulan sesama remaja maupun pergaulan di masyarakat sekitar. Ikatan Remaja Masjid pada umumnya memiliki banyak peranan yang diperankan oleh remaja-remaja yang peduli dan aktif terhadap situasi dan kondisi masyarakat dilingkungannya khususnya tentang masalah keagaman.

Jadi, remaja masjid adalah perkumpulan atau perhimpunan pemuda remaja masjid yang biasanya terdapat di Masjid atau Mushalla, yang menjadikannya sebagai pusat kegiatan pembinaan akidah, akhlak, ukhuwah, keilmuan dan keterampilan. Selain itu, dalam pengertian dalam rana keoorganisasian remaja masjid adalah organisasi otonom yang relatif independen dalam menyelenggarakan urusan rumah tangga organisai dan membina anggotanya. Remaja masjid dapat menentukan sendiri mengenai bagan/struktur organisasi, memilih pengurus, menyusun program, serta melaksanakan berbagai macam kegiatan. ${ }^{22}$

\section{B.3 Pola Pembinaan Remaja Masjid}

Setiap muslim harus bisa bertanggung jawab terhadap dirinya sendiri, keluarga, lingkungan masyarakat, agama, bangsa dan negara. ${ }^{23}$ Organisasi juga memiliki beberapa tanggung jawab, antara lain tanggung jawab terhadap lingkungan masyarakat, tanggung jawab terhadap agama, serta tanggung jawab dalam melaksanakan pekerjaan. Dan setiap manusia pasti akan diminta pertanggung jawabannya. Menurut Zakiyah Daradjat bahwa dalam rangka pembinaan dan pemecahan masalah diperlukan peranan agama, keluarga, sekolah dan organisasi sebagai wadah pengalaman kreativitas. ${ }^{24}$

42.

${ }^{21}$ C. S. T. Kansil, Pancasila Dan Undang-Undang Dasar 1945 (Jakarta: PT Pradya Paramita, 1991),

22 Nevihwa, Rahendra Maya \& Moch. Yasyakur, "Peran Perhimpunan Remaja Masjid At-Taqwa (PERMATA) Dalam Meningkatkan Akhlakul Karimah Masyarakat Kampung Ciampea Ilir Desa Tegalwaru Kecamatan Ciampea Kabupaten Bogor,” Prosa PAI: Prosiding Al Hidayah Pendidikan Agama Islam 1, no. 1 (2018): 14

${ }^{23}$ Abdul Halim, Kholid Fatoni \& Basri Ananda, PAI Bermuatan Budi Pekerti Dan HAM Untuk SMU Kelas 1 (Jakarta: PT Balai Pustaka, 2002), 88.

${ }^{24}$ Zakiah Daradjat, Remaja Harapan Dan Tantangan (Jakarta: Ruhama, 1994), 86. 
Sehubungan dengan kondisi kejiwaan remaja yang berada dalam proses pembentukkan kepribadian maka pembinaannya merupakan suatu keharusan. Dalam rangka pembinaan remaja, untuk menentukan muatan nilai-nilai yang harus diinternalisasikan terlebih dahulu dilihat sasaran yang akan dicapai dalam pembinaan itu.

Di Indonesia dalam kaitannya dengan, pembangunan nasional pembinaan remaja diarahkan pada pencapaian tujuan yaitu:

a. Remaja Mampu mengembangkan kepribadiannya yang konstruktif di dalam segala aspeknya, baik intelektualitas, kerohanian, kecakapan, keterampilan, maupun aspek jasmani atau pisik termasuk kesehatan dan bentuk luar yang segar, kuat dan serasi.

b. Agar remaja Indonesia mampu mengembangkan fungsi sosialnya sebagai bagian dari bangsa keseluruhan untuk membangun Negara, berpartisipasi aktif dalam mempelopori gerak laju pembangunan bangsa, baik dalam membina kesejahteraan lahir dan batin, maupun dalam mengejar berbagai ketinggalan sehingga dapat sejajar dengan warga masyarakat dunia keseluruhan secara terhormat. ${ }^{25}$

\section{B.4 Pola Pembinaan Remaja Masjid Al-Fatah}

Pola pembinaan ramaja masjid adalah suatu cara yang digunakan dalam membimbing jasmani dan rohani berdasarkan hukum-hukum agama Islam meuju kepada terbentuknya kerpibadian umat menurut ukuran Islam.

Pembinaan remaja dalam Islam bertujuan agar remaja tersebut menjadi anak yang shalih yaitu anak yang baik, beriman, berilmu, berketerampilan dan berakhlak mulia. Untuk membina remaja bisa dilakukan dengan berbagai cara dan sarana, salah satunya melalui Remaja Masjid. ${ }^{26}$ Remaja masjid yaitu suatu organisasi atau wadah perkumpulan remaja Muslim yang menggunakan Masjid sebagai pusat aktivitas. Remaja Masjid merupakan salah satu alternatif pembinaan remaja yang terbaik dan dibutuhkan umat. Dengan berorientasi pada aktivitas kemasjidan, keislaman, keilmuan, keremajaan dan keterampilan, organisasi ini dapat memberikan kesempatan bagi anggotannya agar dapat mengembangkan diri sesuai bakat dan kreativitas mereka di bawah pembinaan pengurus/Ta'mir masjid. ${ }^{27}$ Maka dari itu, para remaja masjid akan mendapatkan lingkungan yang Islami sehingga mereka dapat berkreativitas lalu mengembangkannya.

Remaja masjid Al-Fatah Kelurahan Girian Indah Kecamatan Girian Kota Bitung merupakan bentukkan langsung dari Badan Ta'mirul Masjid yang tujuan didirikan agar remaja disibukkan dengan kegiatan-kegiatan positif dan setiap kegiatannya di dukung oleh Badan Ta'mirul Masjid, Badan Keimaman Masjid, Pegawai Syara', Remaja Masjid, Taman Pengajian, Bapak-bapak Majaelis Ta'lim dan Ibu-ibu Majelis Ta'lim. Pengurus BTM harus berupaya untuk membentuk Remaja Masjid sebagai wadah aktivitas bagi remaja muslim.

\footnotetext{
${ }^{25}$ Departemen Agama RI, Remaja Dan Agama Petunjuk Dan Pembinaan (Jakarta: Proyek Penerangan Bimbingan dan Dakwah/Kotbah Agama Islam Pusat, 1984), 27.

26 Aslati et al., "Pemberdayaan Remaja Berbasis Masjid (Studi Terhadap Remaja Masjid Di Labuh Baru Barat)," Masyarakat Madani: Jurnal Kajian Islam Dan Pengembangan Masyarakat 3, no. 2 (2018): 6.

27 Eman Suherman, Manajemen Masjid: Kiat Sukses Meningkatkan SDM Melalui Optimalisasi Kegiatan Umat Berbasis Pebdidikan Berkualitas (Bandung: Alfabeta, 2012), 12.
} 
Sehingga dengan adanya Remaja Masjid tugas pembinaan remaja Muslim akan menjadi lebih ringan. Pengurus BTM, melalui Bidang Pembinaan Remaja Masjid, memberi kesempatan dan arahan kepada Remaja Masjid untuk tumbuh dan berkembang, serta mampu beraktivitas sesuai dengan nilai-nilai Islam.

Oleh karena itu, Remaja masjid Al-Fatah Kelurahan Girian Indah Kecamatan Girian Kota Bitung yang titik penekannya pembinaan remaja dengan:

\section{Menyelaraskan kegiatan remaja masjid dengan aktivitas BTM}

Penyelarasan kegiatan diaksudkan agar terjadi sinergi yang saling menguatkan oleh karenanya remaja masjid dijadikan bagian dari struktur BTM. Remaja Masjid merupakan salah satu diantara bagian-bagian dalam Badan Ta'mirul Masjid, mulai dari Remaja Masjid, Ibu-Ibu Majelis Ta'lim, Bapak-Bapak Majelis Ta'lim, dan Taman Pengajian Al-Qur'an.

"Semua bagian itu merupakan perjalanan yang amat besar bagi sebuah Masjid. Apalagi ketika bagian tersebut aktif dan membuat program-programnya berjalan, maka akan kelihatan kemakmuran dari masjid itu sendiri. Jadi tujuan utamanya agar supaya remaja dapat bersinergi dengan bagian-bagian yang ada di dalam masjid itu." 28

\section{Membentuk karakter islami bagi remaja masjid}

"Remaja Masjid berada di bawah naungan Badan Ta'mirul Masjid. Tujuannya agar pemuda/ pemudi yang berada di lingkungan sekitar masjid Al-Fatah, bisa bersosialisasi sekaligus bersilaturahim, membentuk karakter yang lebih islami, pemikiran-pemikiran yang lebih islami. Karena zaman sekarang banyak pemikiranpemikiran yang masuk dari luar yang sasaran empuknya adalah remaja. Karena mereka pikir remaja merupakan makhluk yang pikirannya masih labil yang sedang mencari jati diri. Makanya harus digodok mulai dari sekarang. ${ }^{29}$ Kemudian, "Imam Masjid terhadap pembinaan akhlak secara khusus dapat dilakukan pada saat kegiatan tadzkir, disitulah keimaman memberikan pengarahan-pengarahan berupa pencerahan rohani dan materi-materi yang berkaitan dengan motivasi atau dorongan untuk remaja masjid untuk senatiasa bangkit, berkarya, berinisiatif dsb." 30

Hal itu selaras dengan beberapa nilai-nilai karakter yang ada pada Permendiknas No. 23 tahun 2006 dan nilai itu dikembangkan oleh Pusat Kurikulum Kemendiknas tahun 2009 yaitu kereligiusan, kejujuran, kecerdasan, ketagguhan, kedemoratisan, kepedulian, kemandirian, berfkir (logis, kritis, kreatif dan inovatif), keberanian mengambil risiko, berorientasi pada tindakan, berjiwa kepemimpinan, kerja keras, tanggung jawab, gaya hidup sehat, kedisiplinan, percaya diri, keingintahuan, cinta ilmu, kesadaran akan hak dan kewajiban diri dan orang lain, kepatuhan terhadap aturan-aturan sosial, menghargai karya dan prestasi orang lain, kesantunan, nasionalisme, dan menghargai keberagaman." 31

\footnotetext{
${ }^{28}$ Rahmad Gobel, Imam Masjid, Wawancara, Tanggal 25 Februari 2017.

${ }^{29}$ Norika Aunaka, Pembina Remaja Masjid, Wawancara, Tanggal 27 Februari 2017.

${ }^{30}$ Rahmad Gobel, Imam Masjid, Wawancara, Tanggal 25 Februari 2017.

31 Dit PSMP Kemdiknas, Pendidikan Karakter Terintegrasi Dalam Pembelajaran Di Sekolah Menengah Pertama (Jakarta: Direktorat PSMP Kemdiknas, 2010).
} 


\section{Memberikan sumbangsi pemikiran dan finansial dalam berorganisasi}

Remaja masjid masih sangat memerlukan sumbangsi pemikiran daripada orang-orang yang tentunya lebih berpengalaman dalam hal berorganisasi agar mereka dengan mandiri menjalankan roda organisasinya

"Imam masjid dan BTM bekerjasama untuk menggeneralisir dan mengindentifikasi seluruh remaja masjid tersentuh oleh Masjid Al-Fatah kemudian dibina. Selain itu, remaja masjid juga dibantu dari segi finasial." "32

\section{Mengadakan kajian agama Islam}

Adanya kajian Islam membantu remaja masjid dalam proses pengembangan diri sebagai generasi Islam yang kemudian menjalankan perannnya ditengah-tengah masyarakat.

"Proses pembinaan diisi dalam kegiatan, salah satunya tadzkir yaitu diselingi dengan ceramah agama. Biar wawasan keislaman tentang Islam mereka itu bisa ada, bukan hanya mereka dapat di bangku sekolah tapi didapat dari tadzkir. Ada juga latihan kultum, biar mereka bisa menumbuhkan rasa percaya diri dan kemampuan berbicara di depan umum. Ada juga tadarusan. Setiap minggu remaja masjid berusaha untuk membuat kegiatan mereka lebih bervariasi, bukan sekedar datang duduk diam pulang." 33

Ada juga macam-macam pembinaan lainnya, seperti pembinaan orientasi, sebelum menjadi anggota remaja masjid para remaja diberikan pembekalan berupa LDK (Latihan Dasar Kepemimpinan). Selanjutnya pembinaan kecakapan yaitu pelatihan khusus dalam belajar komputer. Selanjutnya pembinaan pengembangan kepribadian, pembinaan ini lebih digodok mengenai kepribadian sikap, dan hal itu didapatkan melalui kegiatan-kegiatan yang dilaksanakan oleh remaja masjid itu sendiri. Dan yang terakhir ada pembinaan penyegeraan, pembinaan ini hanya untuk sekedar menambah pengetahuan dan kecakapan yang sudah ada, hampir mirip dengan pembinaan kecakapan.

\section{B.6 Hambatan dalam Pembinaan Remaja Masjid Al-Fatah}

Tidak dapat dipungkiri, bahwa dalam proses pembinaan remaja masjid Al-Fatah pastinya ada hambatan baik dari eksternal maupun internal sehingga strategi dalam pendidikan agama Islam tidak berjalan dengan lancar sebagaimana yang diharapkan, Antara lain:

\section{Tidak sejalannya pemikiran antara pengurus BTM dan Imam Masjid}

Sehubungan dengan hal tersebut seorang informan mengatakan:

"Sesungguhnya dalam segala urusan, hambatan-hambatan itu pasti ada, termasuk dalam membina remaja masjid seperti pengurus Badan Ta'mirul Masjid ataupun Badan Keimaman ada yang tidak sejalan pemikiran. Tetapi hambatan-hambatan itu senantiasa masih bisa diatasi. Baik, dengan cara mengembalikan fungsi karismatika Ta'mirul Masjid ataupun Keimaman Masjid. Dan ketika hambatan itu terjadi

\footnotetext{
${ }^{32}$ Rahmad Gobel, Imam Masjid, Wawancara, Tanggal 25 Februari 2017.

${ }^{33}$ Norika Aunaka, Pembina Remaja Masjid, Wawancara, Tanggal 27 Februari 2017.
} 
langsung melakukan komunikasi, memperbaiki atau menyamakan visi dan misi dalam Islam setelah itu dikembalikan kepada remaja masjid. ${ }^{34}$

\section{Persoalan Umur}

Masa remaja bukan berarti belum berumah tangga, ada yang di masa itu sudah memilih hidup dengan keluarganya sendiri dan ada yang masih menikmati masa-masa ramajanya. Pilihan mereka untuk menikah tak bisa di intervensi oleh BTM maupun Keimaman Masjid karena mereka mempunyai pilihan sendiri. Hal ini informan mengatakan:

"Proses pembinaan mulai dari objek yang menerima binaan dari segi remaja langsung, yaitu persoalan umur. Sebagian dari remaja masjid kita sudah menikah dan berkeluarga. Sehingga banyak yang sudah mengikuti alur kehidupannya masingmasing. Dan tersisalah remaja-remaja yang boleh dikata belum bisa diklasifikasikan remaja akan tetapi diklasifikasikan sebagai remaja." ${ }^{35}$

\section{Kuranganya dukungan dari orangtua dan diri sendiri}

Faktor lainnya yang menjadi kendala pembinaan ramaja masjid adalah kurangnya perhatian dari para orangtua yang membiarkan anaknya bermain tanpa ada pengawasan dan remajanya sendiri tak mau bergabung atau mengikuti dan bahkan merasa bosan dengan kegiatan remaja masjid. Sehubungan dengan hal itu sesuai dengan keterangan informan:

"Masih kurang dukungan dari orangtua dan diri sendiri, (tidak ada teman tidak mau datang) kurang memiliki kepercayaan diri sehingga remaja zaman sekarang lebih memilih pergi ke tempat-tempat yang kurang manfaatnya seperti ke warnet, café dsb." ${ }^{36}$ Selain itu, "Susahnya untuk mengumpulkan teman-teman, dengan alasan tugas sekolah dan memang ada juga yang mengatakan malas untuk datang ke remaja, kepengurusan juga jarang aktif, pengurus juga jarang membuat undangan sehingga teman-teman jadi ragu untuk datang. Dan yang terakhir teman-teman merasa bosan dengan program yang itu-itu terus." 37

\section{Kondisi lingkungan mempengaruhi remaja}

Kondisi lingkungan sangat berpengaruh dalam kehidupan seseorang. Lingkungan dapat membentuk perilaku seseorang dalam berbuat maupun bertindak. Remaja pada zaman sekarang sudah termasuk kategori yang sangat mengkhawatirkan, karena remaja sekarang sudah sangat berbeda dengan remaja zaman dulu. Problematika remaja saat ini sudah menjadi tontonan setiap hari. Berbagai macam tontonan yang disajikan oleh remaja, mulai dari pergaulan bebas, minum minuman beralkohol, dsb, sehingga melahirkan berbagai macam pendapat dan keragaman persepsi mengenai problematika remaja saat ini. Sehubungan dengan hal itu sesuai dengan keterangan informan:

\footnotetext{
${ }^{34}$ Rahmad Gobel, Imam Masjid, Wawancara, Tanggal 25 Februari 2017.

${ }^{35}$ Rahmad Gobel, Imam Masjid, Wawancara, Tanggal 25 Februari 2017.

${ }^{36}$ Norika Aunaka, Pembina Remaja Masjid, Wawancara, Tanggal 27 Februari 2017.

${ }^{37}$ Nursafwa A. Sidik, Ketua Remaja Masjid, Wawancara, Tanggal 26 Februari 2017.
} 
"Problematika remaja sangat kompleks. Dari segi psikis, sosial kebudayaan, lingkungan dsb. Remaja belum bisa menyaring, belum mampu membuat saringan untuk menyaring informasi-informasi yang mereka dapatkan dari dunia maya. Jika mereka mampu membuat perisai, maka remaja bisa tampil menjadi muslim sejati. Remaja mengalami cobaan yang luar biasa karena IPTEK sehingg terbawa arus mengikuti hawa nafsu sesuai dengan apa yang mereka lihat dan mereka temukan. Tanpa disadari sudah melakukan suatu kesalahan-kesalahan yang fatal. Secara global mereka sedang diuji. Apabila bisa melewati maka mereka lolos, jika tidak maka mereka tidak lolos." ${ }^{38}$

Hal itu juga didukung informasi yang didapatkan dari anggota remaja masjid:

"Banyak remaja yang nakal, ada juga yang baik, ada yang ikut kegiatan yang tidak masuk akal, ada yang lebih suka pacaran, ada yang sering nongkrong di tempattempat sunyi, ada anak-anak yang suka naik motor dan ugal-ugalan." 39 Selain itu, "Banyak remaja yang sering melanggar aturan agama, seperti yang saya lihat teman sekelas saya kalau pulang sekolah mereka masih tinggal di dalam kelas dan pacaran, pegang-pegangan tangan dan saling berpelukan. Ada juga remaja yang naik motor sering ugal-ugalan." ${ }^{40}$ Dan beberapa anggota yang sama informasi tentang pengaruh lingkungan terhadap remaja sehingga berdampak pada perilaku dan perbuatannya.

Problematika remaja yang terjadi saat ini yaitu yang pertama, kebanyakan remaja belum bisa menyaring informasi-informasi yang mereka lihat dan mereka baca. Salah satunya dengan berkembangnya Ilmu Pengetahuan dan Teknologi (IPTEK), sehingga mereka seakan terbawa dengan semua hal tanpa disadari mereka sudah melakukan suatu kesalahan yang fatal. Mulai dari berkata-kata yang tidak pantas di media sosial, menonton video-video porno dan membuka situs-situs terlarang dsb. Yang kedua krisis akhlak, remaja saat ini sudah tidak dapat membedakan cara bersikap yang seharusnya terhadap orang yang lebih tua dari mereka. Dan yang terakhir pergaulan bebas, banyak remaja yang lebih memilih bergaul dengan orangorang yang sudah terkenal dengan sebutan anak nakal, karena bergaul dengan mereka akan mendapat julukan anak gaul. Tapi tanpa mereka sadari, sebenarnya mereka telah menjerumuskan diri mereka sendiri dalam jurang kehancuran. Alhasil, banyak diantara mereka yang hamil di luar nikah, menghirup lem ehabon yang dapat memabukan, minumminuman beralkohol dan ada yang sampai tawuran baik antar sekolah atau antar kampung.

Hambatan lainnya ada pada pengurus BTM dan Keimaman Masjid yang sibuk dengan pekerjaannya sehingga proses jadwal pembinaan terbengkalai.

\section{B.7 Upaya dalam Mengatasi Hambatan Pembinaan Remaja Masjid Al-Fatah}

Setiap pembinaan pastinya ada masalah maupun hambatan dalam prosesnya, hal itu bisa datang dari BTM, Keimaman dan remaja itu sendiri. Sehingga prosesnya bisa mengganggu, menghambat, atau bahkan merugikan bagian-bagian lain, karena tidak dapat di

\footnotetext{
${ }^{38}$ Rahmad Gobel, Imam Masjid, Wawancara, Tanggal 25 Februari 2017.

${ }^{39}$ Anastsya Mulyono, Anggota Remaja Masjid, Wawancara, Tanggal 26 Februari 2017.

${ }^{40}$ Nurjannah Maku, Anggota Remaja Masjid, Wawancara, Tanggal 26 Februari 2017.
} 
integrasikan menjadi satu totalitas yang utuh. ${ }^{41}$ Makanya perlu adanya upaya yang kemudian menjadi jalan keluar dari masalah tersebut.

Masalah yang terjadi akan bisa diatasi bilamana ada yang bersedia untuk meminimalisirnya. Hal tersebut dilakukan oleh BTM dan Keimaman yang sudah berinisitif mendirikan remaja masjid, dan berperan dalam mengatasi hambatan dalam pembinaan sesuai dengan hasil wawancara dengan Imam Majid bahwa yaitu dengan tetap membina mereka dan mendukung dari segi finansial organisasi remaja masjid, menciptakan kondisi yang kondusif artinya jangan menunjukkan perselisihan antara pengurus BTM maupun dengan Keimaman karena berbeda pemikiran didepan para remaja masjid, dan jika ada kegiatan yang tidak aktif kiranya dapat mengaktifkannya kembali agar mereka bisa berkarya dan berinovasi dalam melakukan hal-hal yang positif. ${ }^{42}$ Dengan demikian upaya yang dilakukan oleh BTM dan Keimaman masjid adalah tindakan yang benar. Hal tersebut bila tidak dilakukan dapat menyebabkan proses pembinaan akan terhambat.

\section{Penutup}

Berdasarkan permasalahan dan temuan penelitian pola pembinaan kepribadian dan keagamaan remaja masjid di kelurahan Girian Indah, maka disimpulkan bahwa kehadiran organisasi remaja masjid yang dibentuk oleh pengurus masjid (BTM dan Keimaman) mempunyai maksud untuk menghindarkan remaja dari canggih dan mutakhirnya teknologi yang mempunyai andil cukup besar dalam mewarnai gaya hidup remaja yang akhirnya membuat para remaja melakukan hal-hal yang menyimpang sehingga mereka melanggar norma-norma yang ada di masyarakat. Oleh karenanya pola pikir dan perilaku remaja semakin jauh dari ajaran agama Islam.

Lingkungan yang Islami adalah lingkungan yang dibutuhkan remaja untuk membentuk kepribadian remaja. Dengan lingkungan yang Islami dapat memberi kemudahan dalam pembinaan remaja. Bukan hanya pembinaan kepribadian tetapi pembinaan keagamaan juga dapat diajarkan. Maka organisasi remaja masjid merupakan salah satu cara agar remaja dapat membentengi diri dari sesuatu yang negatif. Dalam proses pembinaan yang ada pada remaja masjid Al-Fatah Kelurahan Girian Indah dapat diketahui bahwa adanya menyelaraskan kegiatan remaja masjid dengan aktivitas BTM yang dinisitif oleh pengurus masjid selain itu dengan adanya penyelarasan dapat dmasukkan program kegiatan yang dapat membentuk karakter Islami bagi remaja masjid misalnya kegiatan tadzkir, disitulah keimaman memberikan pengarahan-pengarahan berupa pencerahan rohani dan materi-materi yang berkaitan dengan motivasi atau dorongan untuk remaja masjid untuk senatiasa bangkit, berkarya. Memberikan sumbangsi pemikiran dan finansial dalam berorganisasi sehingga program yang ingin diadakan akan berjalan dengan lancar, serta mengadakan kegiatan tentang kajian agama Islam yang dapat memberikan pemahaman keagamaan. Walaupun didalam prosesnya ada hambatan yang harus dilewati oleh pengurus masjid dan remaja

\footnotetext{
${ }^{41}$ Kartono, Patologi Sosial 2 Kenakalan Remaja, 5.

${ }^{42}$ Rahmad Gobel, Imam Masjid, Wawancara, Tanggal 25 Februari 2017.
} 
masjid yang kiranya harus saling mendukung satu sama lain untuk mencari jalan keluar, sehingga hambatan tersebut dapat diatasi.

\section{DAFTAR PUSTAKA}

Al-Faruq, Asadullah. Panduan Lengkap Mengelola Dan Memakmurkan Masjid. Solo: Pustaka Arafah, 2010.

Aslati, Silawati, Sehani \& Nuryanti. "Pemberdayaan Remaja Berbasis Masjid (Studi Terhadap Remaja Masjid Di Labuh Baru Barat)." Masyarakat Madani: Jurnal Kajian Islam Dan Pengembangan Masyarakat 3, no. 2 (2018): 1-11.

Astuti, Ana Puji, \& Rps, Anike Nurmalita. "Teknologi Komunikasi Dan Perilaku Remaja." Jurnal Analisa Sosiologi 3, no. 1 (2014): 91-111.

Buwaethy, Ahmad. Kriteria Tipologi Masjid. Jakarta: Dirjen Bimbaga Islam, 2004.

Daradjat, Zakiah. Pendidikan Agama Dalam Pembinaan Mental. Jakarta: PT Bulan Bintang, 1982.

. Remaja Harapan Dan Tantangan. Jakarta: Ruhama, 1994.

Departemen Agama RI. Remaja Dan Agama Petunjuk Dan Pembinaan. Jakarta: Proyek Penerangan Bimbingan dan Dakwah/Kotbah Agama Islam Pusat, 1984.

Dit PSMP Kemdiknas. Pendidikan Karakter Terintegrasi Dalam Pembelajaran Di Sekolah Menengah Pertama. Jakarta: Direktorat PSMP Kemdiknas, 2010.

Halim, Abdul, Fatoni, Kholid \& Ananda, Basri. PAI Bermuatan Budi Pekerti Dan HAM Untuk SMU Kelas 1. Jakarta: PT Balai Pustaka, 2002.

Herman. "Pola Pembinaan Remaja Mesjid Nurul Jihad Kelurahan Tipulu Kecamatan Kendari Barat." Al-Izzah: Jurnal Hasil-Hasil Penelitian 8, no. 2 (November 1, 2013): 92-103.

Kansil, C. S. T. Pancasila Dan Undang-Undang Dasar 1945. Jakarta: PT Pradya Paramita, 1991.

Kartono, Kartini. Patologi Sosial 2 Kenakalan Remaja. Jakarta: PT Raja Grafindo Persada, 2002.

Mahmud, Ali Abdul Halim. Karakteristik Umat Terbaik Telaah Manhaj, Akidah Dan Harakah. Jakarta: Gema Insani Press, 1996.

Mangunharjana, A. M. Pembinaan Arti Dan Metodenya. Yogyakarta: Kanisius, 1986.

Marjuni \& AK, Sodiq. "Pola Pembinaan Anak Usia Prasekolah Melalui Prinsip-Prinsip Bermain Sambil Belajar (Studi Di Tempat Penitipan Anak Indrya Paramartha Yogyakarta)." Jurnal Penelitian Dan Evaluasi Pendidikan 3, no. 4 (2001): 62-79.

Nevihwa, Maya, Rahendra \& Yasyakur, Moch. "Peran Perhimpunan Remaja Masjid AtTaqwa (PERMATA) Dalam Meningkatkan Akhlakul Karimah Masyarakat Kampung Ciampea Ilir Desa Tegalwaru Kecamatan Ciampea Kabupaten Bogor." Prosa PAI: Prosiding Al Hidayah Pendidikan Agama Islam 1, no. 1 (2018): 19-27.

Nuwairah, Nahed. "Peran Keluarga Dan Organisasi Remaja Masjid Dalam Dakwah Terhadap Remaja." Al-Hiwar 3, no. 6 (2015): 1-12.

Soetopo, Hendyat \& Soemanto, Wanty. Pembinaan Dan Pengembangan Kurikulum. Jakarta: Bumi Aksara, 1982.

Suherman, Eman. Manajemen Masjid: Kiat Sukses Meningkatkan SDM Melalui Optimalisasi

Prasetio Rumondor, Puspasari M. Y. Gobel 
Kegiatan Umat Berbasis Pebdidikan Berkualitas. Bandung: Alfabeta, 2012.

Taufiq, HN. "Pola Pembinaan Keagamaan Dan Akhlak Mahasiswa (Studi Kasus Di Universitas Muhammadiyah Malang).” Progressiva 4, no. 1 (2010): 45-60.

Wirawan, S. Psikologi Remaja. Jakarta: Raja Grafindo Persada, 2002.

Zulmoran, Noupal, Muhammad \& Aliyah, Sri. "Peran Sosial Keagamaan Remaja Masjid Di Kelurahan Pipa Reja Kecamatan Kemuning Palembang.” Jurnal Studi Agama 1, no. 1 (2017): 41-54. 